\title{
ОСОБЛИВОСТІ РОЗВИТКУ ТУРИЗМУ НА ЗАКАРПАТТІ В ЧЕХОСЛОВАЦЬКИЙ ПЕРІОД (1918 - 1938)
}

У статті розглянуто особливості розвитку туризму на Закарпатті у чехословацький період. Окреслено здобутки у розбудові туристичної інфраструктури, популяризації літніх та зимових видів відпочинку, визначено роль діяльності Клубу чехословацьких туристів.

3'ясовано, щ⿻о в ичей період туризм починає розглядатись як ичілісна галузь народного господарства. Для прийому туристів було відкрито або відремонтовано більше двох десятків туристичних притулків (хат), 400 місиь для ночівлі облаштовано у будівлях державних установ та закладів гостинності. Промарковано майже 1000 км туристичних марирутів. Значна увага приділялася популяризації туристичного потенціалу Закарпаття. Домінували екскурсійний культурно-пізнавальний та активний напрями відпочинку, а курортна рекреачія позначилась певним занепадом.

Ключові слова: туризм, Чехословацька Республіка, Підкарпатська Русь, Закарпаття, Клуб чехословацьких туристів.

Лim. 18.

Bohdana NOSA, restgraduate student, Department of history Ukraine's, Uzhhorod National University (Uzhhorod, Ukraine)bohvul@gmail.com

\section{FEATURES OF TOURISM DEVELOPMENT IN TRANSCARPATHIA IN THE CZECHSLOVAK PERIOD (1918 - 1938)}

The article summarizes the features of tourism development in Transcarpathia in the Czechoslovak period. The achievements in development of tourism infrastructure, popularization of summer and winter types of rescreation were outlined. The role of activity of the Club of Czechoslovak tourists was determined.

It was established, that in the twenties - thirties of the twentieth century in Transcarpathia tourism begins to be seen not only as the direction of leisure of the population, but also as an integral sector of the economy, which is able to effectively use available capacity (natural, cultural, material and technical) and positive impact on the overall socio-economic development of the region More than two dozen tourist shelters (houses) mainly in mountainous areas were opened or renovated for tourists. More than 400 people were equipped to sleep in public buildings and institutions of hospitality. Almost $1000 \mathrm{~km}$ of hiking trails were marked. There were few dozen hotels, restaurants, canteens, coffee houses throughout Transcarpathia. The largest contribution to the development of tourism infrastructure in this period was made by members of the Club of Czechoslovak tourists.

Improvement of transport infrastructure, such as roads, railways, air travel positively influenced the development of tourism.

Much attention is paid to the popularization of tourism potential of Transcarpathia. Tourist guides and maps, some articles in complex journals were published, advertising information was spread on the pages of the press. Some tourist trains from Czechoslovak Republic and abroad were sent to Transcarpathia. Particular interest was shown by German, French, Italian, Hungarian tourists. The greatest admiration of visitors was caused by great mountain views that are complemented with historical and cultural sights, crafts and even household and industrial objects.

Cultural, educational tours and active recreation prevailed, but recreation resorts were affected with decline. Ski tourism also developed. Ski trails on mountain areas were arranged. Ski competitions at various levels organized annually.

Key words: tourism, Czechoslovak Republic, Pidkarpatska Rus, Transcarpathia, Club of Czechoslovak tourists.

Ref. 18. 
Богдана НОСА,

аспирант кафедры истории Украинь

ГВУЗ «Ужгородский наџиональньй университет»

(Ужсгород, Украина)bohvul@gmail.com

\section{ОСОБЕННОСТИ РАЗВИТИЯ ТУРИЗМА НА ЗАКАРПАТЬЕ В ЧЕХОСЛОВАЦКИЙ ПЕРИОД (1918 - 1938 гг.)}

В статье рассмотрены особенности развития туризма на Закарпатье в чехословачкий период. Определены достижения в развитии туристической инфраструктуры, популяризации летних и зимних видов отдыха. Определена роль деятельности Клуба чехословачких туристов

В этот период туризм начинает рассматриваться как иеелостная отрасль народного хозяйства. Для приема туристов было открыто или отремонтировано более двух десятков туристических приютов (домов), 400 мест для ночлега обустроено в зданиях государственных учреждений и заведениях гостеприимства. Промаркированы почти 1000 км туристических маршрутов. Значительное внимание уделялось популяризации туристического потенциила Закарпатья. Доминировали экскурсионный культурно-познавательный и активный направления отдыха, а курортная рекреация сказалась определенным упадком.

Ключевые слова: туризм, Чехословачкая Республика, Подкарпатская Русь, Закарпатье, Клуб чехословацких туристов

Лит. 18.

Постановка проблеми. Протягом двадцятиріччя перебування території Закарпаття у складі Чехословацької Республіки туристична діяльність краю досягнула небаченого до того рівня розвитку. Саме у 20 - 30-ті pp. XX ст. туризм починає розглядатись не лише як напрям відпочинку й дозвілля населення, а й цілісна галузь народного господарства, спроможна ефективно використовувати наявний потенціал (природний, культурний, матеріально-технічний) та позитивно впливати на загальний соціально-економічний розвиток регіону. Швидкими темпами розвивалася туристична інфраструктура, популяризувались нові види туристського відпочинку. Зазначені процеси становлять значний науковий інтерес та потребують окремого дослідження.

Аналіз досліджень. Наукове осмислення історико-політичного, соціально-економічного та культурно-освітнього становища Закарпаття у визначений період представлене багатьма працями, проте дослідження особливостей розвитку туризму широкого висвітлення не набули.

В історичному розрізі розвиток туризму в краї досліджував Ф. Шандор [18], окремі узагальнення здійснені А. Мельником та Ж. Собов [14], В. Фуртієм [17]. Безсумнівно, найбільшу цінність становлять праці 1920 - 30-х рр., зокрема туристичні путівники-довідники І. Крала та А. Свободи [13], Я. Достала [5]; окремі статті тогочасників (Й. Петерле [15], К. Дравецького [6], Ф. Габріеля [3], А. Ільковича [9]) тощо.

Стаття підготовлена $з$ метою вивчення особливостей розвитку туризму на території Закарпаття у чехословацький період.

Виклад основного матеріалу. 20 - 30-ті pp. XX ст. в цілому на Закарпатті позначились пожвавленням розвитку транспортної інфраструктури, містобудування, культурно-освітньої діяльності. Позитивна тенденція спостерігалася і в туристичні сфері, щоправда, з певною переорієнтацією. Якщо в кін. XIX - на поч. XX ст. в краї розвивалась в основному лікувально-оздоровча рекреація, то в чехословацький період такий напрям незатребуваний і поступається загальнокультурному екскурсійному й активному відпочинку.

Курортна діяльність на Закарпатті в цей період позначилася певним занепадом, зумовленим руйнівними наслідками I світової війни та румунської окупації, в результаті яких значних пошкоджень зазнали відомі комплекси у Кобилецькій Поляні, Ужку, Ниліпині, Вишкові (курорт Шаян), Солотвині тощо. Особливого акценту з боку чехословацької влади на відновлення курортної галузі не ставилося, що пізніше викликало шквальну критику з боку угорської сторони та розглядалось як свідомий крок через наявність на чеських землях всесвітньовідомих курортів. 
У 20-х рр. друком почали виходити численні комплексні дослідження, присвячені Підкарпатській Русі, в яких особлива увага приділялася бальнеологічним ресурсам та їх використанню [7, $45-47 ; 8,27-41 ; 12,14-16]$. Відзначався низький рівень облаштування курортних комплексів, а в оцінці, справді, відчувався порівняльний підхід з розвинутими чеськими та словацькими закладами. Наголошувалось й на необхідності значних фінансових ресурсів для їх відновлення й удосконалення.

Протягом наступних років відновлювальні роботи, хоча й частково, все ж проводилися. Шаянським комплексом займалось керівництво Буштинського лісозаготівельного управління [5, 312], неліпинський бальнеологічний комплекс викупило та відновлювало одне з акціонерних товариств $[12,16]$, солотвинські та ужоцька купелі використовувались лише частково. Без реконструкції залишився комплекс у Кобилецькій Поляні. Оздоровчі рекреаційні послуги продовжували надаватись різноманітними закладами у Поляні, Синяку, Квасах, Іванівцях, Мукачеві, Усть-Чорній, Руській Мокрій, Нижньому Солотвині, Ужгороді тощо. В основному, вони мали регіональне значення та ставали лише супутнім місцем туристського відвідання.

Незважаючи на це, мінеральні води у чехословацький період вважалися незмінним атрибутом туристичного потенціалу Закарпаття. У $30-x$ рр. продовжувались дослідження мінеральних джерел, зокрема Ф. Вайснером [1; 2], результати яких були розміщені навіть у ювілейному збірнику про Підкарпатську Русь (1936 р.).

Протягом 20 - 30-х рр. ХХ ст. особливового розквіту на Закарпатті досягають активні напрями відпочинку (пішохідні походи, гірськолижний туризм), включаючи культурно-пізнавальну екскурсійну складову. Активізації туристичних потоків сприяло інфраструктурне забезпечення. Провідну роль у цьому процесі відіграв Клуб чехословацьких туристів (КЧСТ) - громадська організація, яка займалась маркуванням туристичних маршрутів, їх інформаційно-методичним забезпеченням, розбудовою та утриманням туристичних притулків, облагородженням територій та екскурсійних об єктів, популяризацією туризму, пропагандою активного відпочинку тощо.

У Чехословаччині ця організація виникла як правонаступник Клубу чеських туристів, заснованого ще у 1888 р. 3 утворенням республіки вона зазнала суттєвих трансформацій, пов'язаних не лише з перейменуванням та розробкою оновлених статутних документів, а й зі значним розширенням організаційної роботи. У 1922 р. клуб вже налічував 170 відділень та 30 тис. членів на території всієї республіки, а в 1938 - 390 осередків та більше 100 тис. членів (серед них - 8 на території Закарпаття із майже 1200 членами) [11].

Клуб об єднував любителів спортивного відпочинку, активну молодь, зацікавлених осіб та функціонував за допомогою державного фінансування, членських внесків і отриманих прибутків від діяльності окремих засобів розміщення (притулків, готелів) та ресторанів, якими управляв.

Організація, першочергово, орієнтувалась на розвиток гірського літнього (пішохідного) та зимового (лижного) туризму, який вимагав відповідного маркування та облаштування місць для ночівель подорожуючих.

Маркування туристичних маршрутів на території Закарпаття розпочалось на початку 20-х рр. 3 утворенням п’яти відділень КЧСТ в Ужгороді, Мукачеві, Хусті, Рахові та Воловці [15, 95], у 30-х рр. клуб відкрився у Великому Березному, Тячеві та Міжгір'ї $[5,24]$. Кожен осередок виконував маркування на території своєї діяльності. У 1928 році ця спільна робота була представлена як «Ювілейна карпатська стежка» від Ужгорода до Ділового [15, 95]. Довжина маршруту становила 343 км. До нього були підв `ззані 22 промарковані бічні стежки, а загальна протяжність досягала близько 1000 км $[18,71]$.

Маршрутні нитки охоплювали усі туристично привабливі напрями, які користуються популярністю і в наш час: Ужанська долина (від Ужгорода до Ужоцького первалу); Перечин Свалява через Полонину Руну; Воловець, Свалява, Міжгір`я з`єднувались із Боржавськими полонинами; Берегово - з Боржавською долиною; з Хуста долиною р. Ріка йшло сполучення аж до Торуня; з Буштина Тереблянською долиною - до Синевирської Поляни; Тересва - Усть-Чорна через Дубове (із полониною Апецька); із Солотвина стартували маршрути до гірських вершин Рахівського району. 
Швидкими темпами члени клубу розвивали мережу туристичних притулків та станцій. Якщо у 20-х рр. налічувалось 3 десяток таких пунктів відпочинку в Ужгороді, Берегові, Виноградові, Солотвині, Ужку, Мукачеві, Воловці, Ясіню тощо [13], то до 1936 р. їх кількість зросла втричі. Клуб співпрацював із державними органами лісового господарства краю, які володіли розгалуженою мережею лісових доріг, вузькоколійок, десятками водосховищ, що акумулювали воду для сплаву бокорів у верхів'ях рік. Біля водосховищ, гребель, загат лісівники звели житлові будинки для охорони цих штучних водних споруд. На них постійно працюваль декілька десятків лісорубів і бокорашів, для яких була створена система обслуговування й забезпечення харчами. В окремих випадках туристи для нічлігу могли використовувати добре впорядковані будинки для лісників $[18,70]$. Крім того, клуб співпрацював із державними освітніми установами (школами), спілками, закладами гостинності, у приміщенні яких облаштовував туристські пункти.

Таблиия 1.

Станції КЧСТ станом на 1936 р.*

\begin{tabular}{|c|c|c|}
\hline Населений пункт & Місце розташування & Кільк. ліжок \\
\hline м. Ужгород & Руська державна реальна гімназія & 35 \\
\hline М. Берегово & Дім спортивно-виховної організації «Сокол» & 15 \\
\hline смт. Великий Березний & Будівля «Použké banka» & 5 \\
\hline с. Волосянка & Готель «Тайга» & 5 \\
\hline смт. Міжгір`я & Будівля Легіонерської спілки & 6 \\
\hline с. Синевир & Дім дорожніх майстрів & 14 \\
\hline \multirow[t]{2}{*}{ с. Синевирська Поляна } & Будинок лісника на Чорній Ріці & 4 \\
\hline & Ресторан-готель Шафара & 6 \\
\hline с. Торунь & Будівля чеської школи & 5 \\
\hline с. Довге & Будівля чеської школи & 5 \\
\hline \multirow[t]{2}{*}{ м. Мукачево } & Інтернат державної руської гімназії & 31 \\
\hline & Літовельська ресторація & 7 \\
\hline с. Турички (Лумшори) & Будівля лазні & 20 \\
\hline \multirow[t]{2}{*}{ с. Ясіня } & $\begin{array}{l}\text { Будинок державного управління лісового го- } \\
\text { сподарства на г. Окула }\end{array}$ & 4 \\
\hline & Будівля чеської народної школи & 20 \\
\hline смт. Солотвино & Будівля горожанської школи & 28 \\
\hline с. Нижні Ворота & Будівля Руського народного дому & 10 \\
\hline смт. Воловець & Будівля Руського народного дому & 42 \\
\hline с. Збини & Будівля школи & 6 \\
\hline смт. Жденієво & Будівля чеської школи & 10 \\
\hline м. Тячів & Будівля горожанської школи & 4 \\
\hline с. Лопухів & Готель-ресторан Адлера Маєра & 8 \\
\hline смт. Дубове & Готель-ресторан М. Канюки & 6 \\
\hline с. Нересниця & Готель-ресторан Н. Чіка & 5 \\
\hline \multirow[t]{2}{*}{ с. Німецька Мокра } & Готель-ресторан Обербухлера & 10 \\
\hline & Станція з переробки молока на г. Стеняк & 4 \\
\hline смт. Усть-Чорна & Будівля чеської школи & 10 \\
\hline с. Невицьке & Невицький замок & 6 \\
\hline M. Хуст & Будівля чеської школи & 42 \\
\hline
\end{tabular}

Таким чином, облаштовані станції відділень клубу могли розмістити до 400 осіб одночасно. Набір послуг у цих пунктах був різноманітним: міг передбачати лише нічліг, доповнюватисz харчуванням або забезпечувати повний пансіон. Вартість розміщення також коливалась від символіч- 
ної суми до майже двох десятків крон. Діапазон послуг дозволяв мандрівникам облаштовуватись відповідно до своїх фінансових можливостей. Найдорожчим, відтак якісним, було обслуговування у готельних закладах. Наприклад, у Літовельській ресторації (Мукачево) денний пансіон коштував 16 крон $[5,106]$. Члени клубу у таких пунктах могли розміщуватись або безкоштовно, або із суттєвою знижкою на проживання чи інші послуги, наприклад прийом ванн у Лумшорах $[5,149]$. Члени КЧСТ мали певні переваги та знижки й в інших закладах. До прикладу, в с. Ужок готель «Спорт» встановив вартість розміщення для них три крони (замість п’яти) [5, 67]; 20 \% знижки на проживання та 10 на харчування надавалось у гірській хаті «Піп Іван» [5, 179] тощо. Без сумніву, це стимулювало до членства в організації.

Окремої уваги заслуговують туристичні притулки (хати, готелі), відремонтовані або збудовані клубом. Найповніше результати такої роботи виявилися у 30-х рр. У літній період притулки забезпечували ще 300 місць для ночівлі, у зимовий період частина баз не працювала.

Туристичні притулки КЧСТ станом на 1936 р.*

\begin{tabular}{|c|c|c|c|}
\hline $\begin{array}{c}\text { Населений } \\
\text { пункт }\end{array}$ & Місце розташування & $\begin{array}{l}\text { Кільк. } \\
\text { місць }\end{array}$ & Примітки \\
\hline $\begin{array}{l}\text { смт. Великий } \\
\text { Березний }\end{array}$ & Тур. хата на г. Явірник & 11 & $\begin{array}{l}\text { Будівля Держуправління лісового } \\
\text { господарства, яку КЧСТ відре- } \\
\text { монтував у } 1936 \text { році }\end{array}$ \\
\hline $\begin{array}{l}\text { с. Синевирсь- } \\
\text { ка Поляна }\end{array}$ & Тур. хата на березі о. Синевир & 20 & $\begin{array}{l}\text { Перебудована } 1936 \text { року з окреми- } \\
\text { ми кімнатами для чол. та жін. }\end{array}$ \\
\hline \multirow[t]{2}{*}{ м. Рахів } & $\begin{array}{l}\text { Туристичний дім-готель та два } \\
\text { окремі приміщення для ночівлі }\end{array}$ & $24 / 20$ & $\begin{array}{l}\text { Збудований протягом } 1932-1934 \\
\text { pp. Кошторис складав } 1 \text { млн. крон } \\
{[15,96]}\end{array}$ \\
\hline & Тур. хата, г. Думен & 10 & Збудована 1935 р. \\
\hline \multirow[t]{6}{*}{ с. Богдан } & $\begin{array}{l}\text { Гірська хата під г. Говерла (ліжка; } \\
\text { ночліг на підлозі) }\end{array}$ & $12 / 20$ & $\begin{array}{l}\text { Відремонтована } 1934 \text { р., працюва- } \\
\text { ла у літній сезон }\end{array}$ \\
\hline & $\begin{array}{l}\text { Тур. хата біля потоку Балцатул } \\
\text { (ліжка; ночліг на підлозі) }\end{array}$ & $10 / 15$ & \\
\hline & $\begin{array}{l}\text { Тур. притулок біля клаузури Балца- } \\
\text { тул (нічліг на підлозі) }\end{array}$ & 15 & Відкритий у липні 1935 року \\
\hline & $\begin{array}{l}\text { Тур. притулок біля клаузури Квас- } \\
\text { ний (нічліг на підлозі) }\end{array}$ & 5 & Відкритий у липні 1935 року \\
\hline & $\begin{array}{l}\text { Тур. притулок, г. Васкул (нічліг на } \\
\text { підлозі) }\end{array}$ & 20 & \\
\hline & $\begin{array}{l}\text { Тур. притулок на Межипотоках } \\
\text { (нічліг на підлозі) }\end{array}$ & 20 & \\
\hline с. Ділове & Гірська хата під г. Піп Іван & 40 & $\begin{array}{l}\text { Відремонтована та збільшена у } \\
\text { 30-х рр. }\end{array}$ \\
\hline с. Скотарське & Тур. хата біля Скотарського перевалу & 20 & Відкрита у 1936 році \\
\hline смт. Воловець & Гірська хата під г. Плай & 34 & \\
\hline с. Кам`яниця & $\begin{array}{l}\text { Тур. хата на г. Плішка (нічліг на } \\
\text { нарах) }\end{array}$ & 16 & \\
\hline
\end{tabular}

Наймасштабнішими проектами КЧСТ було відкриття туристичного готелю у м. Рахів та ресторану в Невицькому замку. Сам замок перебував під опікою ужгородського відділення КЧСТ з 1922 р. $[13,33]$.

Задля об'єктивності, необхідно зазначити, що до розвитку туристичної інфраструктури докладали зусиль й представники інших організацій. Наприклад, у 1934 р. спортивною секцією Академічного союзу з Варшави збудовані польська туристична хата під Чорною Горою (50 місць) 
[5, 170] та «Притулок на Пантирі ім. II Карпатської бригади Легіонів польських» неподалік с. Лопухово (20 місць) [5, 242]. У віданні Польського туристичного товариства перебувала база під Говерлою (на Заросляку) на 120 ліжок [5, 170].

3 кінця XIX ст. на території т. з. Фелвідейку (верховини) діяла Угорська карпатська асоціація громадська організація туристичного спрямування. Її зусиллями також облаштовувались притулки (напр., г. Говерла, Піп Іван), готувалися путівники тощо. У 1918 р. на територіях, що ввійшли до складу Чехословаччини, асоціація була розпущена, а ії майно конфісковане. У 20-х pp. організація відновила свою роботу під іншою назвою «Карпатський клуб» («Karpathen verein»), через судові позови зуміла повернути деякі туристичні бази, відкрила осередки у Берегові (1925) та Виноградові (1935). Свою діяльність вела автономно, перебуваючи у постійному протистоянні із КЧСТ [10, 108-112].

Розвиток інфраструктури забезпечувався й зусиллями приватних та державних ініціатив. У 1935 р. відкрився туристичний притулок на Свидовецькому Драгобраті під г. Близниця (6 ліжок); гірська хата на полонині Квасівський Менчул (15 ліжок) [5, 173-174]; гірська хата (готель) «Піп Іван» (40 місць), зорієнтована на літній гірський та зимовий лижний відпочинок (денний пансіонат становив 20 крон) [5, 179]. Мисливська хата «На кордоні» діяла неподалік с. Німецька Мокра $[5,257], 100$ ліжок для туристів було облаштовано на залізничній станції Бескид у новозбудованому вокзалі [5, 206].

Індустрія гостинності була представлена кількома десятками готелів, ресторанів, їдалень, кав ’ярень по всій території Закарпаття. Найбільш високими кількісними показниками відзначались такі міста, як Ужгород, Мукачево, Берегово, Тячів, Виноградово.

Позитивно впливала на розвиток туризму наявна транспортна інфраструктура. Розбудова шосейних доріг забезпечувала транспортну доступність до віддалених туристичних зон. Користувались популярністю серед туристів вузьколійки (Ужгород - Анталівці, Берегово - Кушниця, Тересва - Усть-Чорна, Зимір - Козьмещик), мережа яких протягом чехословацького періоду активно розширювалась, а та, що вже функціонували, отримали дозвіл на пасажирські перевезення.

Швидке міжнародне перевезення забезпечувалось авіасполученням завдяки збудованому в Ужгороді державному аеродромові (1929 р.). Міжнародні лінії сполучали Чехословаччину, Румунію, Радянський Союз. Квиток внутрішнього прямого перельоту з Праги до Ужгорода коштував 280 крон (на початку 30-х рр. середній денний заробіток на Підкарпатській Русі становив 24 крони) $[5,23]$.

Значна увага надавалася популяризації туристичного потенціалу Закарпаття. Друком виходили туристичні путівники та карти, окремі статті у комплексних виданнях про Підкарпатську Русь, рекламна інформація поширювалась на шпальтах преси. У 1924 р. в Мукачеві друком виходить «Туристичний путівник Підкарпатської Русі та Словаччини на схід від Кошиць» I. Крала та А. Свободи [13]. За своїм змістом це унікальне видання, в якому вперше зведена інформація про мережу туристичних маршрутів краю 3 детальним описом, картами та практичними рекомендаціями щодо їх проходження.

У 30-х рр. опубліковано туристичний путівник-довідник Я. Достала «Підкарпатська Русь» [5], який грунтовно презентує туристичні можливості Закарпаття. Також він є автором туристичних роз`яснень топографічних карт, що видавалися КЧСТ.

3 метою популяризації в Ужгороді діяв «Союз по пропаганді Підкарпатської Русі», який у 1936 р. мав свою канцелярію й у Празі. Саме з діяльністю цієї інституції на сторінках ювілейного збірника А. Ількович пов язував збільшення закордонних туристичних потоків до нашого краю [9, 11]. Відомо, що в цьому ж році з ініціативи Народогосподарської ради успішно відбувся конкурс кращих статей та фото у друкованих виданнях, покликаний популяризувати туризм на Закарпатті $[6,188]$.

Залізничним управлінням Чехословаччини відправлялись окремі туристичні поїзди до Закарпаття, особливо у період збору винограду. Кілька поїздок із-за кордону було організовано спеціальним бюро подорожей «Чедок». Особливу зацікавленість виявляли туристи із Німеччини, де навіть функціонувало окреме бюро з організацій поїздок до Підкарпатської Русі, зокрема Рахова та Ясіні. За приблизними підрахунками К. Дравецького, протягом року у цій місцевості туристи залишали майже 5 млн. крон [6, 186-188]. Відвідували край французи, італійці, голландці, 
угорці. В угорській пресі навіть у чехословацький період поширювалась рекламна інформація про можливості відпочинку на Закарпатті, у тому числі санаторного. Як одне із найпривабливіших місць позиціонувався курортний комплекс у Поляні $[16,4]$.

Найбільше захопення у гостей краю викликали чудові гірські краєвиди, які доповнювалися історико-культурними пам`ятками, народними промислами і навіть господарсько-промисловими об`єктами. 3 цікавістю оглядались замки Закарпаття; центри лозоплетіння в Ільниці, Великій Копані, Текові, Нижніх Воротах, Колодному тощо, ткацтва килимів у Сільці, Арданові, Ганичах, Липчі, Вишкові та ін. Відвідувалися лісосплавні комплекси у Синевирі та Синевирській Поляні, Ясіню, Німецькій Мокрій; в останніх двох та в Богдані об`єктами туристського відвідання були й клаузури (греблі).

Приваблювало Закарпаття своїми виноградниками (Ужгородщина, Мукачівщина, Виноградівщина); такими цікавими об єктами, як кузня «Гамора» в Лисичеві, соляні шахти у Солотвині, метеорологічна станція у Воловці, найдовший дерев'яний міст Чехословаччини у Королеві (420 м), ферма з розведення черепах у Мукачеві, пивоварний завод в Підгорянах, тютюнові плантації у Велятині та багато інших.

Велика увага приділялась розвитку гірськолижного туризму, осередками якого стали гірські масиви в Ужку, Волосянці, Рахові, Ясіню, Скотарському, Воловці. В останньому діяв лижний трамплін, відкритий ще в австро-угорський період. КЧСТ щороку організовував лижні змагання різного рівня $[15,95]$. Значну зацікавленість у такому відпочинку проявляла і місцева молодь, щоправда, вона вимушено задовольнялася саморобним спорядженням. Потребували удосконалення й лижні траси, які не завжди відповідали вимогам безпеки та правилам лижного спорту.

Особлиий вплив на успішний розвиток туризму мала діяльність місцевого населення. До широкого загалу неодноразово $[9,11 ; 6,188]$ лунали заклили активніше долучатися до розбудови туристичних об'єктів, до популяризації свого краю, результати якої прямо впливають на соціально-економічний рівень їхнього життя.

У 1928 р. земський уряд видав окремий документ, в якому наголошувалось, що однієї прирордної краси Підкарпатської Русі не вистачить, щоб розвивати туризм. Для цього необхідні зусилля місцевого населення. Особлива увага зверталась на роботу вчителів сільських шкіл як основних вихователів місцевої молоді. Діти мали щомісяця дві години вивчати основи розвитку туризму. Насамперед культурно ставитися до іноземців; вміти відповісти на прості запитання або ж відвести їх до школи чи нотаря для отримання інформації; знати відомості про цікаві туристичні об`єкти (музеї, пам`ятки, мінеральні джерела); залізничні станції, приблизний рух транспорту, довколишню місцевість тощо [4, 353-354].

Потреба в економічному зростанні Закарпаття наводилась і як агрумент спонукання чеських та словацьких туристів відвідувати ці землі $[3,325]$. Окрім того, туризм вважався ефективним способом міжкультурного обміну та зближення.

Висновки. Загалом, розвиток туризму на Закарпатті у чехословацький період досяг значного розмаху. Зусиллями потужних громадських ініціатив за державної підтримки вдалось суттєво покращити туристичну інфраструктуру, пожвавити туристичні потоки, популяризувати літні та зимові види відпочинку, зміцнити туристично привабливий образ краю. Очевидно, що така тенденція позитивно впливала на соціально-економічний розвиток краю, але в загальному місцеве населення залишалось бідним, особливо у кризовий період 30-х рр.

Унаслідок чергової окупації краю протягом 1938 - 1939 рр. матеріально-технічні досягнення останнього двадцятиліття зазнали суттєвої шкоди, а подальший розвиток туристичної галузі вимагає окремого дослідження.

\section{СПИСОК ВИКОРИСТАНИХ ДЖЕРЕЛ І ЛІТЕРАТУРИ}

1. Wiesner F. Vodstvo a minerálni prameny zemé Podkarpatoruské: Druhé vydáni / F. Wiesner. - Užhorod, 1935. $-68 \mathrm{~s}$.

2. Wiesner F. Země Podkarpatská. Přirodni bohatstva / F. Wiesner // Publikace pro zem Podkarpatská Rus / Sestavil G. Bianchi. - Bánška Bystřica, 1932. - S. 38-43. 
3. Gabriel F. Turistika na Podkarpatské Rusi // Podkarpatská Rus: Sbornik hospodářského, kulturniho a politického poznáni Podkarpatské Rusi / Redigoval J. Zatloukal. - Bratislava,1936. - S. 322-325.

4. Гарагонич В. В. Транскордонне співробітництво України: мости через кордони. Монографія / В. В. Гарагонич. - Ужгород: Карпати, 2011. - 432 с.

5. Достал Я. Європейське коріння / Путівник-довідник / Переклад, упоряд., доповн. Ю. Фатули. Ужгород: Карпати, 2016. - 328 с.

6. Дравецкій К. Развитіе туристики на Подк. Руси / К. Дравецкій // Подкарпатская Русь за годы 1919 - 1936. - Ужгородь, 1936. - С. 184-188.

7. Drahný V. Podkarpatská Rus, její př́rodní a zemědělské poměry / V. Drahný, F. Drahný. - Praha, 1920. $113 \mathrm{~s}$.

8. Drahný F. Geologické poméry Podkarpatske Rusi / F. Drahný // Podkarpatská Rus: obraz pomérů přirodnich, hospodářských, politických, cirkevnich, jazykových a osvětových / Redigovali J. Chmelař, S. Klima, J. Kécas. - Praha: Orbis, 1923. - S. 27-41.

9. Ільковичь А. Значеніе заграничной посещаемости для Подкарпатской Руси / А. Ільковичь // Рamátnik vénovaný u Přiležitosti Převzeti nové budovy Zemského úřadu pro Zemi Podkarpatskou v Užhorodě. - Užhorod, 1936. - S. 10-11.

10. Jellinek J. A magyar természetjárás története / J. Jellinek. - Budapest, 1939. - 117 old.

11. Клуб чеських туристів: офіційний веб-сайт. - [Електронний ресурc]. - Режим доступу: https://www. kct.cz/cms

12. Kozminova A. Podkarpatská Rus: práce a život lidu po stránce kulturní, hospodářské a národopisné / A. Kozminova. - Karlin, 1922. - $128 \mathrm{~s}$.

13. Král J. Turistický průvodce Podkarpatskou Rusi a Slovenskem východně od Košic / J. Král, A. Svoboda. Mukačevo, 1923. - $116 \mathrm{~s}$.

14. Мельник А. В. Особливості становлення організованого туризму Закарпаття (кінець XIX - початок XX століття) / А. В. Мельник, Ж. В. Собов // Наукові записки Тернопільського національного педагогічного університету ім. В. Гнатюка. Серія: Географія. - 2016. - № 2. - С. 123-129.

15. Peterle J. Turistika na Podkarpatské Rusi / J. Peterle // Publikace pro zem Podkarpatská Rus / Sestavil Gustav Bianchi. - Bánska Bystřica: Slovan, 1932. - S. 95-96.

16. Poljana (Polana) fürdő... // Nyirvidék. - Nyiregyháza, 1930. - LI évf. - 122 szám. (május 31). - old. 4.

17. Фуртій В. Розвиток туризму на Закарпатті у період Чехословаччини 1918 - 1938 pp. / В. Фуртій // Східноєвропейський історичний вісник. - Дрогобич: Посвіт, 2017. - Вип. 3. - С. 114-117.

18. Шандор Ф. Ф. Туризм / Ф. Ф. Шандор // Закарпаття 1919 - 2009 років: історія, політика, культура / Під ред. М. Вегеша, Ч. Фединець; [Редколег.: Ю. Остапець, Р. Офіцинський, Л. Сорко, М. Токар, С. Черничко; Відп. за вип. М. Токар]. - Ужгород: Поліграфцентр «Ліра», 2010. - С. 69-72.

\section{REFERENCES}

1. Wiesner F. Vodstvo a minerálni prameny zemé Podkarpatoruské: Druhé vydáni / F. Wiesner. - Užhorod, 1935. $-68 \mathrm{~s}$.

2. Wiesner F. Země Podkarpatská. Přirodni bohatstva / F. Wiesner // Publikace pro zem Podkarpatská Rus / Sestavil G. Bianchi. - Bánška Bystřica, 1932. - S. 38-43.

3. Gabriel F. Turistika na Podkarpatské Rusi // Podkarpatská Rus: Sbornik hospodářského, kulturniho a politického poznáni Podkarpatské Rusi / Redigoval J. Zatloukal. - Bratislava,1936. - S. 322-325.

4. Harahonych V. V. Transkordonne spivrobitnytstvo Ukrainy: mosty cherez kordony. Monohrafiia / V. V. Harahonych. - Uzhhorod: Karpaty, 2011. - 432 s.

5. Dostal Ya. Yevropeiske korinnia / Putivnyk-dovidnyk / Pereklad, uporiad., dopovn. Yu. Fatuly. - Uzhhorod: Karpaty, 2016. $-328 \mathrm{~s}$.

6. Dravetskiy K. Razvitiye turistiki na Podk. Rusi / K. Dravetskiy // Podkarpatskaya Rus za hody 1919 1936. - Uzhhorod,1936. - S. 184-188.

7. Drahný V. Podkarpatská Rus, její přírodní a zemědělské poměry / V. Drahný, F. Drahný. - Praha, 1920. $113 \mathrm{~s}$.

8. Drahný F. Geologické poméry Podkarpatske Rusi / F. Drahný // Podkarpatská Rus: obraz pomérů přirodnich, hospodářských, politických, cirkevnich, jazykových a osvětových / Redigovali J. Chmelař, S. Klima, J. Kécas. - Praha: Orbis, 1923. - S. 27-41.

9. Ilkovich A. Znacheniye zahranichnoy poseshchayemosti dlya Podkarpatskoy Rusi / A. Ilkovich // Památnik vénovaný u Přiležitosti Převzeti nové budovy Zemského úřadu pro Zemi Podkarpatskou v Užhorodě. - Užhorod, 1936. - S. 10-11.

10. Jellinek J. A magyar természetjárás története / J. Jellinek. - Budapest, 1939. - 117 old. 
11. Klub cheskykh turystiv: ofitsiinyi veb-sait. - [Elektronnyi resurs]. - Rezhym dostupu: https://www.kct.cz/ $\mathrm{cms}$

12. Kozminova A. Podkarpatská Rus: práce a život lidu po stránce kulturní, hospodářské a národopisné / A. Kozminova. - Karlin, 1922. - $128 \mathrm{~s}$.

13. Král J. Turistický průvodce Podkarpatskou Rusi a Slovenskem východně od Košic / J. Král, A. Svoboda. Mukačevo, 1923. - $116 \mathrm{~s}$.

14. Melnyk A. V. Osoblyvosti stanovlennia orhanizovanoho turyzmu Zakarpattia (kinets XIX - pochatok XX stolittia) / A. V. Melnyk, Zh. V. Sobov // Naukovi zapysky Ternopilskoho natsionalnoho pedahohichnoho universytetu im. V. Hnatiuka. Seriia: Heohrafiia. - 2016. - № 2. - S. 123-129.

15. Peterle J. Turistika na Podkarpatské Rusi / J. Peterle // Publikace pro zem Podkarpatská Rus / Sestavil Gustav Bianchi. - Bánska Bystřica: Slovan, 1932. - S. 95-96.

16. Poljana (Polana) fürdő... // Nyirvidék. - Nyiregyháza, 1930. - LI évf. - 122 szám. (május 31). - old. 4.

17. Furtii V. Rozvytok turyzmu na Zakarpatti u period Chekhoslovachchyny 1918 - 1938 rr. / V. Furtii // Skhidnoievropeiskyi istorychnyi visnyk. - Drohobych: Posvit, 2017. - Vyp. 3. - S. 114-117.

18. Shandor F. F. Turyzm / F. F. Shandor // Zakarpattia 1919-2009 rokiv: istoriia, polityka, kultura / Pid red. M. Vehesha, Ch. Fedynets; [Redkoleh.: Yu. Ostapets, R. Ofitsynskyi, L. Sorko, M. Tokar, S. Chernychko; Vidp. za vyp. M. Tokar]. - Uzhhorod: Polihraftsentr «Lira», 2010. - S. 69-72.

Стаття надійшла до редакиії 31.05.2017 p. 